\title{
A Preliminary Report on the Effects of Summer Pinching upon the Carbohydrate and Nitrogen Contents of the Japanese Pear Shoots**
}

\author{
Y. Arisi and H. ITo \\ College of Agriculture, Tokyo Imperial University
}

In Japan, the fruit growers pinch not rarely in summer the vigoronsly growing shoots of fruit trees, intending to get flower buds on them, and it is believed that this practice brings about in the pinched shoots the carbohydrate accumulation, and the carbohydratenitrogen ratio becomes, consequently, high enough to differenciate flower buds, for the growing tip of shoots, which spends carbohydrates much, is removed and the elongation of shoots is checked by pinching. It is, however, doubtful whether the carbohydrate accumulation is actually produced by pinching, and no investigation which studied the chemical changes taken place in the pinched shoots, las been reported.

The present brief report of the investigation which is one phase of the stndies on the physiological foundation of the tree responses to pruning, deals with the changes in chemical constituents of the pinched shoots of the Japanese pear trees.

\section{Material and Methods}

'Three, cire. 20-year-old Japanese pear trees (Pyrus serotina Rehder) of the variety Inamuraki, grown in the orchard of the Tokyo Imperial University at Komaba, 'Tokyo, were selected for the study. Many pairs of shoots were chosen for uniformity, and tabulated, one of each pair being pinched and the other remaining untreated as check. In the pinching treatment of this study, the soft terminal portion of shoots was removed at the point 2 or $3 \mathrm{~cm}$. below the tip with the nails of fingers. After several weeks the pinched and the untreated shoots were collected, immediately stripped of leaves and the fresh weights determined.

* A part of the investigations which are conducted with aid of the subsidiary foundation for natural scientific researches in the Educational Department of the Government.

* This paper was presented before the horticultural section at the fourth annual meeting of the Nippon Nogaku Kwai, held at Tokyo on April 9, 1933. 


\section{Methods of Chemical Analysis}

Preservation. The samples were clipped as rapidly as possible into small pieces from one to three mm. long by means of a pruning shears. The picees were tessed into an Erlenmeyer flask, and after adding calcium carbonate and enough 95 per cent alcehol so as to make the final concentration 80 per sent, the flask was heated on the water bath to gentle boiling for 30 minutes.

Extraction. The alcohol was poured off of the residue and filtered through a hardened paper. The residue was dried in a large evaporating dish and ground to pass through an 80-mesh sieve and extracted with 80 per cent alkohol using an Allin's reverse condenser until the percolates were colorless.

Analysis of the extract. (1) Nitrogen. The extract was cleared with neutral lead acetate and the diphenylamine nitrate test was performed. In no case a positive test being obtained, determinations were made by the Kjeldahl method. 'The distillation was made with the Shioiri-Okuda's apparatus using methyl red indicator with $0.02 \mathrm{~N}$ sodium hydroxide. (2) Carbohydrates. The aliquots of extract which had been evaporated were taken up in water, cleared with neutral lead acetate and delcaded with sodium oxalate. Redncing power was determined by Fehling's solution. The cuprous oxide was determined by the Bertland method. Non-reducing sugars and glucoside were hydrolysed using dilute hydrochloric acid.

Analysis of the residue. (1) Carbohydrates. a, Water soluble polysaccharides. A $2 \mathrm{gm}$. sample of the residue was extracted with water for 12 hours. The results were calculated as dextrose. $b$, Starch. The residue from the above treatment was washed into an Erlenmeyer flask and heated in the boiling water bath for 30 minutes to gelatinize starch. After cooling to $38^{\circ} \mathrm{C}$, an aliquot portion of a solution of takadiastase was added so that $0.1 \mathrm{gm}$. of enzyme preparation was present. It was then incubated for 48 hours with $2 \mathrm{cc}$. of toluene. At the end of this period the solution $\vec{t}$ was heated to boiling in the boiling water bath for 15 minutes to render the enzymes inactive. The results were calculated by the R. L. Shriner method. e, Acid-hydrolysable polysaccharides. The insoluble residue from the starch determination was transferred to a flask. After adding water and dilute hydrochloric acid the flask was heated under air condenser for $2 \frac{1}{2}$ hours in a boiling water bath. The results were calculated as dextrose. (2) Nitrogen. Nitrogen was determined by the Kjeldahl method as mentioned in the case of soluble nitrogen. 


\section{Results}

In 1931, the shents were pinched on June 16, and the simples for chemical :ualysis were taken every seven days after the tratment.

A summary of the chemical analysis of the untreated and the pinched shoots is presented in Table 1. In this table, we cannct sec any difference in the carbohydrate and nitrogen contents between the untreated and the pinched shoots. The seasmal changes of the carbohydrate and nitrogen contents in the Japanese pear shoots were in agreement with those in the apple shoots reported by Harvey(1). Namely, water, soluble solids, and soluble and insoluble nitrogen decreased throngh the growing season, and insoluble solids, sugars, polysaccharides, total carbohydrates, and the carbohydrate-nitrogen ratio inereased as the scason progressed.

In 1931, the shoots were pinehed when their most active growth nearly ended (Fig. 1), and it was thought that pinching might be conducted too late to bring about

Table 1.- Seasonal Changes of the Chemical Composition in the Untrcated and the Pinched Shoots of the Japancse Pear Trees-1931, Results expressed upon the Dry Weight Basis, The Shoots pinched on June 16.

\begin{tabular}{|c|c|c|c|c|c|c|c|}
\hline · & \multicolumn{7}{|c|}{ Untreated } \\
\hline & $\begin{array}{c}\text { June } \\
30\end{array}$ & $\begin{array}{c}\text { July } \\
7\end{array}$ & $\begin{array}{c}\text { July } \\
14\end{array}$ & $\begin{array}{c}\text { July } \\
21 \\
\end{array}$ & $\begin{array}{c}\text { July } \\
28 \\
\end{array}$ & $\begin{array}{c}\text { Aug. } \\
4\end{array}$ & $\begin{array}{c}\text { Aug. } \\
11\end{array}$ \\
\hline Water & 261 & 216 & 185 & 207 & 181 & 177 & 167 \\
\hline Soluble solids & 20.01 & 17.79 & 16.09 & 14.59 & 12.97 & 12.17 & 7.78 \\
\hline Insoluble solids & 79.99 & 82.21 & 83.91 & 85.41 & 87.03 & 87.83 & 92.22 \\
\hline Direct reducing sugars & 3.06 & 2.94 & 3.61 & 2.33 & 2.92 & 3.41 & 4.59 \\
\hline Non-reducing sugars & 3.82 & 3.52 & 4.83 & 3.24 & 3.48 & 4.02 & 5.29 \\
\hline Water-soluble polysaccharides & 0.38 & 0.40 & 0.32 & 0.52 & 0.39 & 0.63 & 0.50 \\
\hline Starch & 1.14 & 1.38 & 1.29 & 1.39 & 1.37 & 1.56 & 1.69 \\
\hline $\begin{array}{l}\text { Acid-hydrolysable } \\
\quad \text { polysaccharides }\end{array}$ & 4.68 & 5.17 & 4.54 & 4.68 & 6.30 & 6.37 & 7.93 \\
\hline Total carbohydrates & 13.08 & 33.41 & 14.57 & 12.14 & 14.46 & 15.99 & 20.00 \\
\hline Soluble 'nitrogen & 0.29 & 0.24 & 0.22 & 0.20 & 0.18 & 0.16 & 0.15 \\
\hline Insoluble nitrogen & 0.86 & 0.81 & 0.81 & 0.77 & 0.77 & 0.77 & 0.78 \\
\hline Total nitrogen & 1.05 & 1.05 & 1.03 & 0.97 & 0.95 & 0.93 & 0.93 \\
\hline $\mathrm{C} / \mathrm{N}$ & 12.46 & 12.77 & 14.15 & 12.52 & 15.22 & 17.19 & 21.51 \\
\hline
\end{tabular}




\begin{tabular}{|c|c|c|c|c|c|c|c|}
\hline & \multicolumn{7}{|c|}{ Pinched } \\
\hline & $\begin{array}{c}\text { June } \\
\mathbf{3 0}\end{array}$ & $\begin{array}{c}\text { July } \\
7 \\
\end{array}$ & $\begin{array}{c}\text { July } \\
14 \\
\end{array}$ & $\begin{array}{c}\text { July } \\
21 \\
\end{array}$ & $\begin{array}{c}\text { July } \\
28 \\
\end{array}$ & $\begin{array}{c}\text { Aug. } \\
4 \\
\end{array}$ & $\begin{array}{c}\text { Aug. } \\
11\end{array}$ \\
\hline Water & 272 & 221 & 178 & 196 & 188 & 177 & 158 \\
\hline Soluble solids & 16.13 & 17.07 & 15.44 & 14.52 & 13.60 & 10.29 & 8.94 \\
\hline Insoluble solids & 88.87 & 82.93 & 84.56 & 85.48 & 86.40 & 89.71 & 91.06 \\
\hline Direct reducing sugars & 2,63 & 3.07 & 3.47 & 2.26 & 3.64 & 3.48 & 4.11 \\
\hline Non-reducing sugars & 3.27 & 3.64 & 3.98 & 3.01 & 4.12 & 3.89 & 5.34 \\
\hline Water-soluble polysacchrides & 0.39 & 0.41 & 0.43 & 0.57 & 0.40 & 0.65 & 0.50 \\
\hline Starch & 1.13 & 1.18 & 1.29 & 1.36 & 1.40 & 1.54 & 1.60 \\
\hline $\begin{array}{l}\text { Acid-hydrolysable } \\
\qquad \text { polysaccharides }\end{array}$ & 4.66 & 5.55 & 4.60 & 4.61 & 6.27 & 6.50 & 7.22 \\
\hline Total carbohydrates & 12.08 & J3.85 & 13.77 & 11.81 & 15.83 & 16.06 & 18.77 \\
\hline Soluble nitrogen & 0.23 & 0.23 & 0.18 & 0.18 & 0.17 & 0.17 & 0.16 \\
\hline Insoluble nitrogen & 0.90 & 0.88 & 0.83 & 0.81 & 0.81 & 0.83 & 0.78 \\
\hline Total nitrogen & 1.13 & 1.11 & 1.01 & 0.99 & 0.98 & 1.00 & 0.94 \\
\hline$C, N$ & 10.69 & 12.48 & 10.73 & 11.93 & 16.15 & 16.06 & 19.97 \\
\hline
\end{tabular}

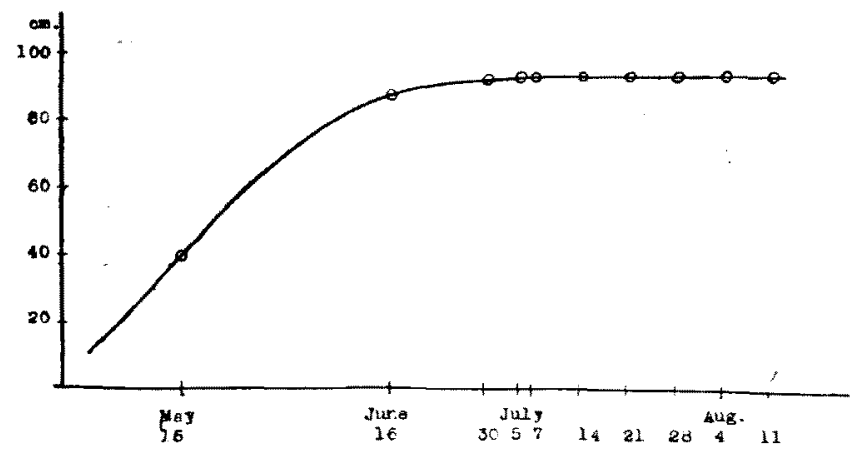

Fig. 1. Growth Curve of the Imamuraki Pear Shoots

remarkable changes in chemical constituents. Moreover, a collected shoot was treated in chemical analysis as a whole, not being separated into terminal and basal portion.

In 1932, therefore, the shoots were pinched on May 15, when they were making rapid growth, and collected together with check shoots on July 5. When the shoots were pinched, their average length was $47.32 \mathrm{~cm}$., and when the shoots were collected, the untreated shoots were $97.32 \mathrm{~cm}$. lung in average. The second growths: 
produced on the pinched shoots were removed soon after they appeared. The collected untreated shonts were divided into four portions: (1) the tip, which consisted of the upper 3 to $4 \mathrm{~cm}$.; (2) the upper middle, which consisted of 25 to $30 \mathrm{~cm}$. upper part next to the tip; (3) the lower middle, which consisted of 25 to $32 \mathrm{~cm}$. part above the base and the upper end of this portion corresponded to the point at which the other shoot of its pair was pinched; (4) the base, the lower 6 to $S \mathrm{~cm}$. The pinched shoots were divided into two halves, upper and basal.

The results of the chemical analysis in 1932 are summarized in Tables 2 and 3. Comparing the carbohydrate and nitrogen contents of the pinched shoots with those of the base and the lower middle portion corresponded to the pinched shoots in the untreated shoots, the percentages of reducing sugars, water soluble polysaccharides and starch were very slightly larger in the pinched shoots, but that of acid-hydrolysable polysacharides was smaller, and the amounts of total carbohydrates were slightly smaller in the pinched shoots than in the corresponded portions of the untreated shoots. The

Table 2.- Chemical Constituents of the Untreated and the Pinched Shrots,1932. Per Cent Dry Weight. The shoots pinched on May 15, the Samples collected on July 5 .

\begin{tabular}{|c|c|c|c|c|c|c|}
\hline & \multicolumn{4}{|c|}{ Untreated } & \multicolumn{2}{|c|}{ Pinched } \\
\hline & Base & $\begin{array}{l}\text { Lower } \\
\text { middle }\end{array}$ & $\begin{array}{l}\text { Upper } \\
\text { middle }\end{array}$ & Tip & $\begin{array}{c}\text { Basal } \\
\text { half }\end{array}$ & $\begin{array}{l}\text { Upper } \\
\text { half }\end{array}$ \\
\hline Water & 125 & 150 & 170 & 208 & 131 & 146 \\
\hline Soluble solids & 14.87 & 16.52 & 16.65 & 24.91 & 14.28 & 15.41 \\
\hline Insoluble solids & 85.13 & 83.48 & 83.35 & 75.09 & 85.72 & 84,59 \\
\hline Direct reducing sugars & 2.77 & 2.29 & 2.24 & 2.11 & 2.82 & 2.91 \\
\hline Non-reducing sugars & 2.63 & 3.75 & 3.65 & 2.61 & 3.03 & 2.64 \\
\hline Water-soluble polysnccharides & 0.69 & 0.69 & 0.68 & 0.54 & 0.74 & 0.73 \\
\hline Starch & 0.93 & 0.89 & 0.79 & 0.65 & 1.02 & 0.97 \\
\hline $\begin{array}{l}\text { Acid-hydrolysable } \\
\text { polysaccarides }\end{array}$ & 6.45 & 5.26 & 4.94 & 3.91 & 5.78 & 5.12 \\
\hline Total carbohydrates & 13.47 & 12.88 & 12.30 & 9.82 & 13,39 & 12.37 \\
\hline Soluble nitrogen & 0.13 & 0.13 & 0.18 & 0.53 & 0.13 & 0.36 \\
\hline Insoluble nitrogen & 0.58 & 0.64 & 0.75 & 1.91 & 0.72 & 1.15 \\
\hline Total nitrogen & 0.71 & 0.77 & 0.98 & 2,44 & 0.85 & 1.51 \\
\hline$C / N$ & 18.97 & 16.73 & 13.23 & 4.02 & 15.75 & 8.19 \\
\hline
\end{tabular}


Table 3.- Chemical Constituents of the Untreated and the Pinched Shouts,1932. Por Cent Fresh Weight.

\begin{tabular}{|c|c|c|c|c|c|c|}
\hline & \multicolumn{4}{|c|}{ Untreated } & \multicolumn{2}{|c|}{ Pinched } \\
\hline & Base & $\begin{array}{l}\text { Lower } \\
\text { middle }\end{array}$ & $\begin{array}{l}\text { Upper } \\
\text { middle }\end{array}$ & Tip & $\begin{array}{l}\text { Basal } \\
\text { half }\end{array}$ & $\begin{array}{l}\text { Upper } \\
\text { half }\end{array}$ \\
\hline Water & 55.61 & 60.06 & 62.90 & 67.56 & 56.59 & 59.36 \\
\hline Soluble solids & 6.60 & 6.60 & 6.72 & 8.08 & 6.20 & 6.28 \\
\hline Insoluble solids & 37.79 & 38.34 & 30.38 & 24.36 & 37.21 & 34.35 \\
\hline Direct reducing sugars & 1.25 & 0.92 & 0.90 & 0.68 & 1.22 & 1.18 \\
\hline Non-reducing sugars & 1.19 & 1.50 & 1.47 & 0.85 & 1.31 & 1.07 \\
\hline Water-soluble polysaccharides & 0.33 & 0.33 & 0.30 & 0.23 & 0.37 & 0,35 \\
\hline Starch & 0.52 & 0.43 & 0.35 & 0.93 & 0.52 & 0.47 \\
\hline $\begin{array}{l}\text { Acid-hydrolysable } \\
\text { polysaccharides }\end{array}$ & 3.09 & 2.42 & 2.21 & 1.69 & 2.93 & 2.46 \\
\hline Total carbohydrates & 6.38 & 5.60 & 5.23 & 3.73 & 6.35 & 6.03 \\
\hline Soluble nitrogen & 0.05 & 0.05 & 0.04 & 0.17 & 0.06 & 0.14 \\
\hline Insoluble nitrogen & 0.31 & 0.31 & 0.34 & 0.83 & 0.36 & 0.55 \\
\hline Total nitrogen & 0.36 & 0.36 & 0.38 & 1.00 & 0.42 & 0.69 \\
\hline $\mathrm{C} / \mathrm{N}$ & 17.72 & 15.56 & 13.89 & 3.73 & 15.12 & 8.74 \\
\hline
\end{tabular}

pinched shoots, especially its upper portions, were evidently richer in nitrogen contents, both soluble and insoluble nitrogen, than the corresponded portions of the cheek shoots.

From the data presented it will be said that pinching increases the percentage of nitrogen, while it affects very little the carbohydrate contents, and the carbohydratenitrogen ratio becomes consequently lower in the pinched shoots, just in opposition to the believed conception.

In Tables 1 and 2, it ean be also noticed that the regional changes in chemical constitucnts of the Japanese pear shoots are in accord with those of the apple 齐 shoots reported by Harvey (1). Those substances, water, soluble solids, and nitrogen, which decreased through the growing season, were most abundant in the tip of the shoots and least abundant in the base, and conversely, those substances, insoluble sulids, sugars, polysaccharides, total carbohydrates, and the carbohydrate-nitrogen ratio, which increased through the growing season, were least abundant in the tip and most. abundant in the base. 


\section{Discussion}

The chemical changes produced in the ringed plus defoliated shoots in Harrey's experiments with apples (1) are very interest in relation to the present investigation. In his ringing plus defoliation treatment the shoots were ringed at the point 6 to $9 \mathrm{~cm}$. above the base when they grew to be 30 to $40 \mathrm{~cm}$. long and the leaves on the portion above the ringed point were removed. The most remarkable effect produced in the basal portion of the ringed plus defoliated shoots was rather large increase in perentages of nitrogen, and the total carbohydrates varicd in the opposite dircetion but the changes were relatively not so great. From this result obtained by Harvey it may be suggested that the summer pruning will increase nitrogen greatly and decrease carbohydrates, because, as Harvey noticed, this treatment would give nearly the same effects on the chemical composition of the basal portion balow the ringed point with these produced by a complete removal of the upper portion of the shoots, i. e., summer pruning.

In his pruning studies with apples Hooker (2) reported that winter pruning (heading) induced a rapid increase in the amount of nitrogen and decreased that of starch and sugar in the cut ends of the shoots.

Pruning, either summer or winter pruning, is, therefore, a treatment which causes a fall in the value of the carbohydratc-nitrogen ratio, increasing nitrogen and decreasing carbohydrates. As pinching practised in the present experiment is a kind of summer pruning, it may be reasonable that pinching produced the chemical changes same in trend with those which should be induced by pruning.

If pinching produces carbohydrate accumulation on account of removal of the growing point which spends much carbohydrates, then in the untreated normal growing shoots the rate of increasing in carbohydrates should be remarkubly higher in the later periorl of growing scason when the elongation of shoots nearly ceased than in the early period when the shoots are growing very rapjdly, and also the formation of flower buds should be affected more remarkably by pinching performed in the period of active growing than by that practised later when shoot elongation nearly ceases. However, neither is the casc. Harvey's data (1) showed that the rate of increasing in total carbohydrates of apple shoots in the perial after the active growth nearly ceased. was not higher than that in the period of rapid growing, and Kawaguchi (3) reported that in his studies with the Japanese pear trees that shoots headed in the 
middle of May when they were growing rapidly, formed flower buds rarely, while many of the shoots headed at the end of June or in early July when their elongation declined or nearly ended, formed flower buds.

\section{Conclusion}

The results obtained in this investigation show that the most remarkable effect of pinching on the chemical changes in the shoots is the rather large increase of nitrogen. This suggests that in the case where flower bud formation is brought about by pinching, the increases of nitrogen should be, therefore, considered as a cause of flower bud formation, when it is interpreted from the point of carbohydrates and nitrogen relationships.

\section{Literature Cited}

(1) Harves, E. M. A study of growth in surnmer shoots of the apple with special consideration of the role of carbohydrates and nitrogen. Oregon Agr. Exp. Sta. Bull. $200,1923$.

(2) Honker, H. Changes produced in apple trees by various types of pruning. Missouri Agr. Exp. Sta. Res. Bull. 72, 1924

(3) Kawaben, M. Effects of summer pruning on development of secondary growth and flower bud formation of the Japanese pear shoots (in Japanese). Agriculture and Horticulture, 6: 563-569, 1929. 